\title{
The Influence of Fur Farming on the Local Economy in Poland
}

\author{
Chrystian FIRLEJ ${ }^{1}$, Krzysztof FIRLEJ ${ }^{2}$, Sebastian KUBALA ${ }^{2}$ \\ ${ }^{1}$ Agricultural University of Kraków, Cracow, Poland \\ chriskrk@poczta.onet.pl \\ ${ }^{2}$ Cracow University of Economics, Cracow, Poland \\ krzysztof.firlejeuek.krakow.pl, sebastian.kubala03@gmail.com
}

\begin{abstract}
Modern farms are seen as a source of social and economic benefits in the development of the local economy. When discussing the problem of fur breeding it should be emphasized that fur fur has both usefulness and commercial value. In the past their main advantage was protection from cold and unfavorable weather conditions. Over time, they became a currency, emphasized the signs of power, and pointed to a social position and a sign of elegance. The consequence of the exchange of markets for the economy is also interesting. It can be predicted that as a result of the presumed ban on agriculture in Poland, the difference will be fulfilled by countries such as Denmark, Germany, Russia and China. Ten years after Poland's accession to the European Union, enthusiasts are faced with serious difficulties if they continue to invest in fur production, as initial drafts of animal protection legislation are expected to phase out in the coming years.
\end{abstract}

Keywords: Modern Farms, Fur Farming, Local Economy.

\section{Introduction}

The origins of the fur farming industry in Poland go back to the 1990s. The good quality of production allowed developing a high position on the fur market, which is often perceived as one of the most modern special sectors of agriculture. Modern farms are perceived as a source of social and economic benefits in development of the local economy. It has been raised more and more controversy regarding the issues of possible benefits connected with the maintenance of this industry recently. Discussing the problem of fur farming it should be emphasized that fur skins have both utility and trade values. In the past their main function was a protection against cold and adverse weather conditions. With time they became a currency; they emphasized the signs of power as well as indicated the social position and were the sign of elegance. Fur skins are also often combined with other fabrics as well as they are used as coats or jackets finishes. In the past the fur skins were obtained from a wild and half-wild farming but in the 20th century there were attempts to domesticate these animals and the specialized farms were built, which started to produce the fur skins on a mass scale. The quality of these skins differs significantly from the skins of animals living in the 
wild as the only aim of the farming is to obtain skins. In the production process there is a constant breeding perfecting of the quality of fur coating, colouring, animals temper, body weight and a size of skins [6]. It should be also emphasized that breeding animals compared with living in the wild are usually better fed which results in bigger body weight, beautiful fur skins, less damages and highly variable colouring $[1,2,5,9]$. The aim of this article is to present the impact of fur farming on the local economy in Poland. The locations and number of fur farms in Poland are shown as well as the current production of fur skins in the chosen European countries and the annual fur skins production in the years 2006-2016. The final stage of the research was to define the impact of fur farms on the local environment.

\section{The aim and research methodology}

The main aim of the study was to provide an illustrative presentation of a current state and financial results achieved in fur farming in Poland, which became the matter of interest of many breeders, scientists and politicians in 2017. Showing this state enabled to indicate directions and extent of fur farming impact on the local economy in Poland. In the operational and analytical part of the article, to present received data, the chosen time series methods were used as well as the graphic and table presentation concerning location and number of carnivorous farms and fur animals in Poland, production of fur skins in the selected European countries and annual production of mink skins.

\section{The current state and the research results}

In 2016 there were 1130 fur farms in Poland, of which a significant proportion (especially the farming of carnivorous fur animals) is located in the North-Western Poland. The majority of farms are located in Greater Poland voivodeship and Pomeranian voivodeship (fig. 1). 


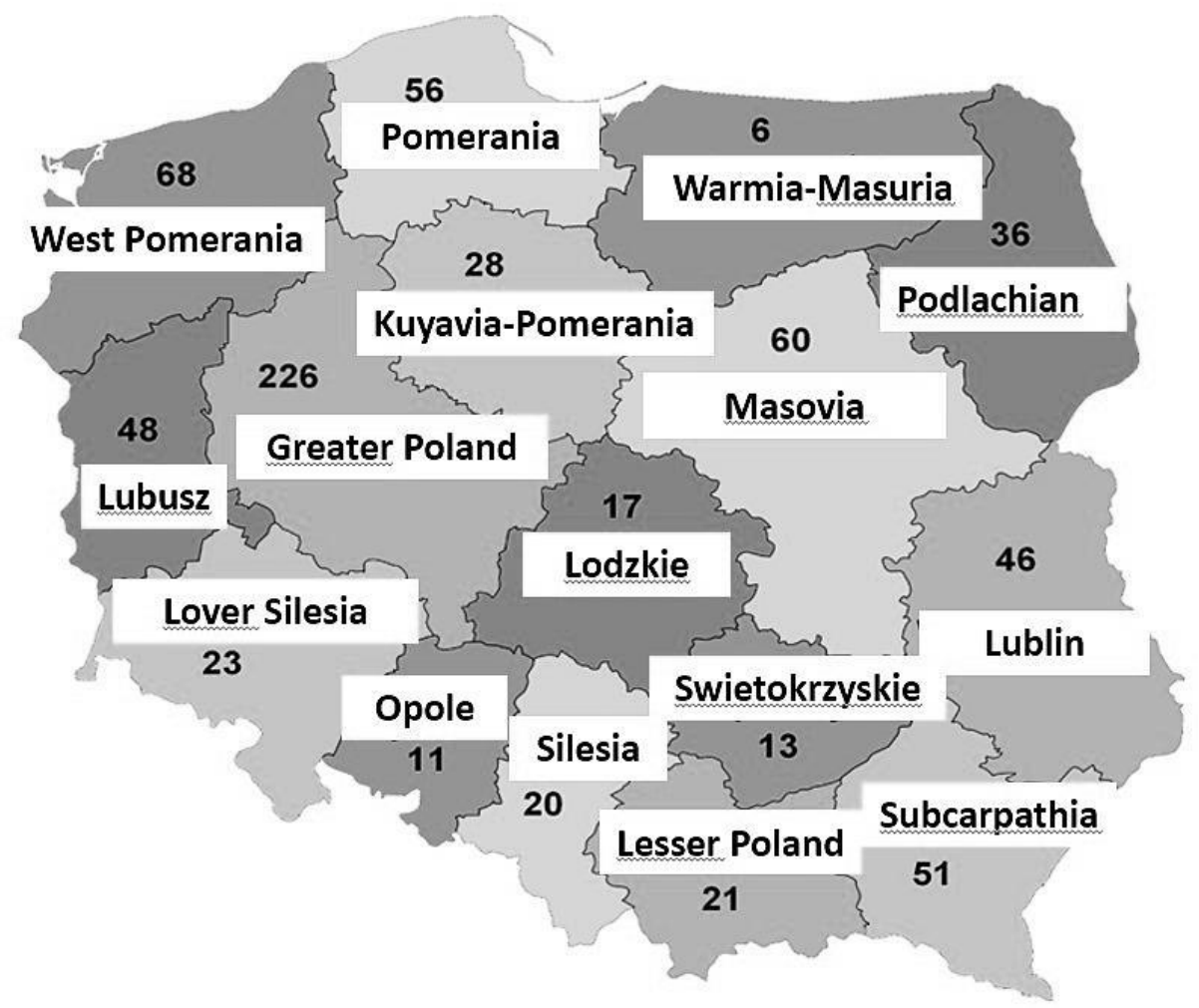

Fig. 1. The location and number of carnivorous fur farms in Poland.

In terms of fur skins production Poland belongs, following Denmark, to the hegemons on the European market (table 1).

Table 1. The production of skins in chosen European countries in 2016 (in units), source: [3].

\begin{tabular}{lrrrr}
\hline & Denmark & Poland & Finland & Netherlands \\
\hline Minks & 17100000 & 8500000 & 1940000 & 4000000 \\
Foxes & 2500 & 50000 & 2300000 & 0 \\
Raccoon dogs & 0 & 10000 & 150000 & 0 \\
Chinchillas & 45000 & 80000 & 0 & 0 \\
In total & 17147500 & 8640000 & 4390000 & 4000000 \\
\hline
\end{tabular}

The annual upwards trend in the number of mink skins production in the years 20062016 is noticeable (fig. 2). In 2016 8,5 million mink skins were produced, representing $13 \%$ of the world production. 


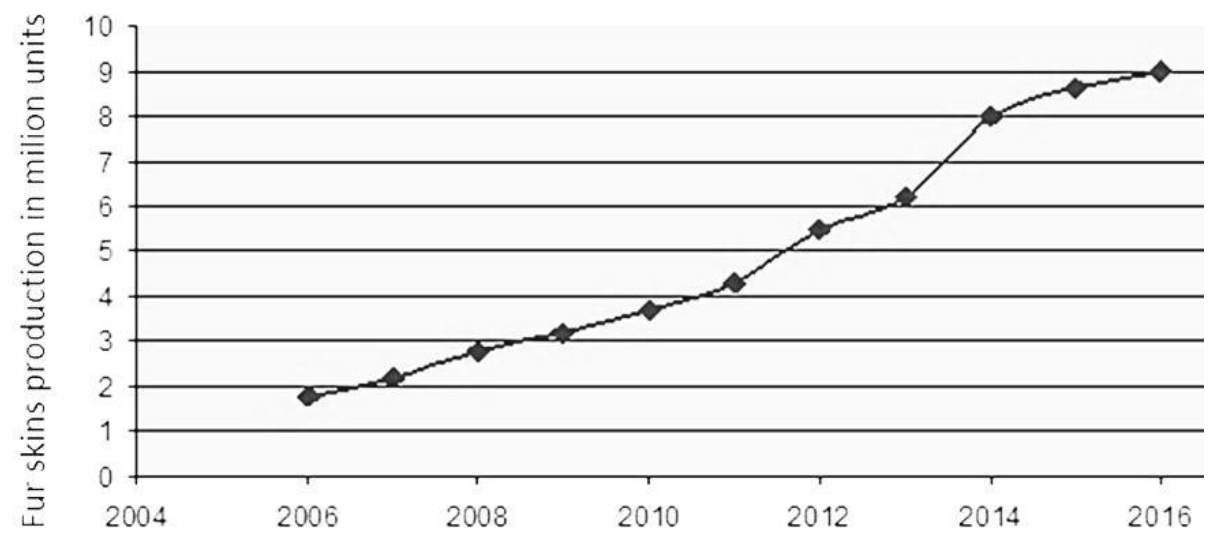

Fig. 2. The annual mink skins production in the years 2006-2016, source: [4].

The production of fur skins in the individual European countries in 2016 appears quite interesting (tab. 2), where the leaders in the industry are Denmark and Poland. Further positions with far smaller level of production are occupied by Finland, the Netherlands, Lithuania, Greece and Sweden. It is worth emphasising that at present in some European countries there is a total ban on fur farming (Great Britain, Austria, Slovenia, Croatia) and in the others a public debate is conducting on introducing such a ban. As a consequence, a tendency to develop fur farming in Eastern Europe (including Poland) may change and move into production in China and Russia. In the light of the appearing reports on the state of farms in these countries there are concerns if they will be properly controlled and if the rules regarding the animal welfare will be observed [7].

Table 2. The production of fur skins in the individual European countries in 2016, source: [3].

\begin{tabular}{|c|c|c|c|c|c|c|}
\hline \multirow[b]{2}{*}{ Country } & \multirow{2}{*}{$\begin{array}{c}\text { Number } \\
\text { of } \\
\text { farms }\end{array}$} & \multicolumn{5}{|c|}{ Fur skins production } \\
\hline & & Minks & Foxes & $\begin{array}{c}\text { Raccoon } \\
\text { dogs }\end{array}$ & Chinchillas & In total \\
\hline Belgium & 19 & 160000 & 0 & 0 & 0 & 160000 \\
\hline $\begin{array}{l}\text { Bosnia and } \\
\text { Herzegowina }\end{array}$ & 50 & 0 & 0 & 0 & 9000 & 9000 \\
\hline Bulgaria & 3 & 100000 & 0 & 0 & 0 & 100000 \\
\hline $\begin{array}{l}\text { Czech } \\
\text { Republic }\end{array}$ & 10 & 20000 & 500 & 0 & 0 & 20500 \\
\hline Denmark & 1533 & 17100000 & 2500 & 0 & 45000 & 17147500 \\
\hline Estonia & 40 & 46000 & 15000 & 0 & 6000 & 67000 \\
\hline Finland & 914 & 1940000 & 2300000 & 150000 & 0 & 4390000 \\
\hline France & 13 & 140000 & 0 & 0 & 0 & 140000 \\
\hline Greece & 98 & 1400000 & 0 & 0 & 0 & 1400000 \\
\hline
\end{tabular}




\begin{tabular}{lrrrrrr} 
Spain & 54 & 750000 & 0 & 0 & 0 & 750000 \\
Netherlands & 185 & 4000000 & 0 & 0 & 0 & 4000000 \\
Ireland & 3 & 150000 & 0 & 0 & 0 & 150000 \\
Iceland & 30 & 174000 & 0 & 0 & 0 & 174000 \\
Lithuania & 131 & 1500000 & 1500 & 0 & 6000 & 1507500 \\
Latvia & 8 & 500000 & 5000 & 0 & 3000 & 508000 \\
Germany & 13 & 130000 & 0 & 0 & 2000 & 132000 \\
Norway & 340 & 700000 & 110000 & 0 & 0 & 810000 \\
Poland & 144 & 8500000 & 50000 & 10000 & 80000 & 8640000 \\
Romania & 153 & 245000 & 0 & 0 & 13000 & 258000 \\
Serbia & 52 & 0 & 0 & 0 & 15000 & 15000 \\
Slovakia & 1 & 4500 & 0 & 0 & 0 & 4500 \\
Sweden & 80 & 1000000 & 0 & 0 & 0 & 1000000 \\
Hungary & 200 & 0 & 0 & 0 & 14000 & 14000 \\
Italy & 30 & 160000 & 0 & 0 & 0 & 160000 \\
Total & 5104 & 38719500 & 2484500 & 160000 & 193000 & 41557000 \\
\hline
\end{tabular}

\section{$4 \quad$ Fur farming and the local community}

A very important question is what impact the maintenance of the fur farming industry has on the local economy. A really significant element providing an answer to this question is a thorough study of the potential benefits and costs of the analysed industry (table 3).

Table 3. The impact of fur farms on the local area.

\begin{tabular}{lcc}
\hline & Farm & \\
\hline $\begin{array}{l}\text { Production of skins as a } \\
\text { valuable export product }\end{array}$ & $\begin{array}{c}\text { Activation of rural areas } \\
\text { by creating workplaces }\end{array}$ & $\begin{array}{c}\text { Benefits connected with } \\
\text { UPPZ utilization }\end{array}$ \\
\hline
\end{tabular}

It is an obvious fact that the farms employ a certain amount of people. In Polish farms 10000 people is employed. The report on the impact of fur farming on the local economy in Poland prepared by the Polish Industry of Fur Animals Farmers presents that a farm keeping 10000 of females is a potential source of employment at the level on average 15 employees (plus 10 additional during the season). A farm keeping of over 25000 females employs 50 permanent employees and 45 seasonal employees. Making such the number of people redundant is a risk of increasing unemployment especially in the areas with a high rate of structural unemployment. The only solution in such a situation is to retrain these people but in case of less educated people that could be difficult. It is also stated that 40000 people are employed in the companies cooperating with the farms. It refers to the enterprises with a mainly mass production which will not contribute to major turmoil in these goods production. 
An important argument is the environment protection as fur farming contributes to utilization of slaughterhouse waste. The annual utilization is between 400000 to 600 000 tons waste. There is a question of what to do with the waste in case of close-down of the industry. Unfortunately the Polish industry is still not developed enough in this matter so there is only possible to utilize abroad, which consequently is connected with moving costs to the foreign companies. Another important argument is the location of fur farms. They are mainly located on soils of low agricultural usefulness.

Important postulates refer to the economic issues. The basic question is regarding the economic benefits from the farms. The estimation of the potential income is difficult. The special issue refers to the boroughs. Furthermore, there is no clear answer what impact the farmers have on the development of a borough. Are they a significant element in their functioning? Do they influence on the investment development in each area? The fur farming significantly injects public finances. It is obviously indisputable that this industry supports the budget by returning an income tax, local tax, tax on goods and social security contributions. It is important to mention the figures from $\mathrm{PwC}$ report. The total input of the farmers in Polish economy was estimated for 1,3 billion złotych in 2013 of which the added value generated by the farmers was 570 million złotych. Te report also stated that the income generated by the farms were in total 587 million złotych (of which 274 million złotych of the farmers and their employees). However, what is a benefit fraction in proportion to liabilities?

It is vital to reconsider the issues regarding law and legislative solutions in the countries that do not have significant moral, law and economic problems like Denmark. However, should not the total ban (the Czech Republic) or phasing out the farming in the other countries (the Netherlands) raise a serious question mark on the factors responsible for that?

In the report 'The impact of fur farming on the local economy in Poland' it is shown that a demand for fur skins is strongly related to the climatic conditions - cold winters guarantee high prices. Another important factor is fashion. At present it is estimated that furs are presented at 2/3 the most prestigious shows in Milan, Paris, New York and London. On luxury goods like furs the vital influence has also incomes and views of retail customers. In the world where customers more and more consciously purchase various goods, the fur industry takes actions to meet demands. The answer for that is pursuing to the transparency of the industry and implementation of the scientific programme WelFur aiming to assess animal welfare. If a farm passes the controls within this programme, will receive a certificate proving farming in accordance with the animal welfare principles. Welfur is initiated by the European Trade Organisation and supported by Kopenhagen Fur, Saga Furs and NAFA. Since 2020 auction houses will sell only mink and fox skins from farms possessing WelFur certificates.

Fig. 3 presents the average price and annual production of mink skins in the years 1983-2014. In the season 2016/2017 the average price of mink skins in auction houses was 35 EUR. In case of polar foxes the average price was 78 EUR and silver foxes 64 EUR. For chinchillas the average price was 45 EUR. The average prices for fur skins 
coming from Poland are similar to the average European prices, which proves their good quality [8].

The Report of Government Inspectorate from 2015 causes a lot of concerns as it shows that almost $90 \%$ of farming do not respect the environment protection demands, half of the farming is run in illegal premises and one in three farms operates against veterinary regulations.

A great reason for concern is the clear signals of controversial farming methods in Wielkopolska region. It is obvious that it poses a seroius problem but was there considered to take actions aiming at decreasing or the complete liquidation of these signals? Polish farms are regulated by one of the most restrictive legislation and they are subject to supervision of the Veterinary Inspection, Environmental Protection Inspectorate or Building Control Inspectorate. The Code of Good Practices was also introduced. There are a lot of proposals of improvements regarding development of the industry: the change of farming methods, the change of meterage of living space of animal and more frequent controls of farmers. The question is how the farmers respond to that. Are they willing to cooperate in order to liquidate the negative aspects regarding the farming? There are vital signals from the farmers that they want to obtain the standardization of work conditions. The important action is also to be determining postulates aiming at liquidation of quasi-farming. Liquidation of farms raises a question if their total liquidation does not cause an emergence of illegal farming.

A considerable controversy refers to worries among the inhabitants of the fur farm areas. These regions are less attractive, there is a negative effect on the environment and groundwater or worsening of the inhabitants' quality of functioning mainly due to unpleasant stench. The talks with the members of the local governments provide some interesting findings. They are unanimous that fur farms are not a burden to the local communities and if they appear they often turn out unreasonable. A lack of negative effect on a development of rural tourism and agrotourism was also stated. 


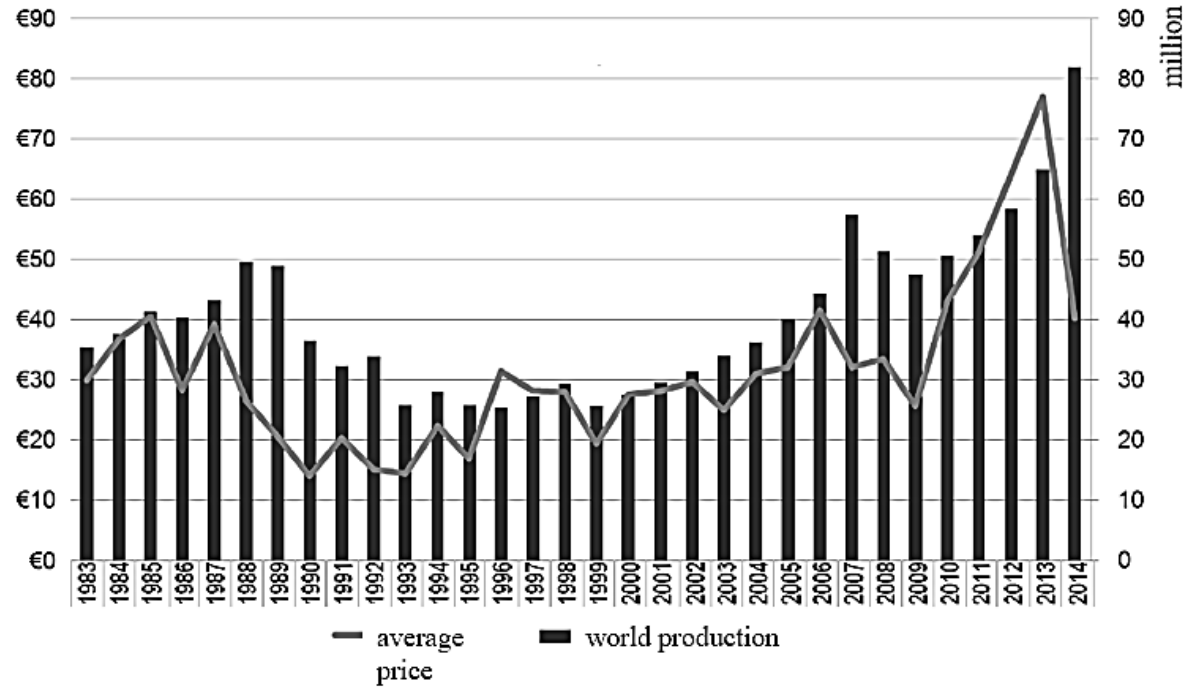

Fig. 3. The average price and annual production of mink skins in the years 1983-2014, source [8].

An interesting issue is also the consequence of markets replacement for the economy. It can be predicted that as a result of a presumptive ban of farming in Poland, the gap will be filled by such countries like Denmark, Germany, Russia and China.

It is worth referring to the survey conducted to recognize the fur farming industry. However, due to a small number of respondents (4,4\% farms in Poland) it is difficult to assess the veracity of the answers to the whole trial. It also applies to the farms located in the Western Pomeranian Voivodeship.

Importantly, a half of the surveyed farm owners is pessimistic about the development of the industry and $2 / 3$ of surveyed declared the withholding of investment as a consequence of legislative work on the industry liquidation. Taking these data into consideration, is the fur farming in Poland necessary? What is a reason for farming if the significant number of respondents is going to withhold their investment and the research findings show that $90 \%$ of farms are the main source of income.

\section{Conclusion}

A decade after the accession of Poland to the European Union the entrepreneurs are facing a serious dilemma if it is still worth investing in fur farming since the preliminary drafts of the proposed laws on animal protection presume the phasing out of this industry in the upcoming few years. The source query of literature as well as journalistic studies, source data and interviews with the farmers resulted in the following findings: 
- Poland is the leading fur skins producer and in 2016 was the second in Europe producing 8,64 million of fur skins, had the second position in the number of produced mink skins $-8,5$ million and the first in the number of produced chinchilla skins $-80,000$. What is more, 50,000 of fox skins and 10,000 of raccon dog skins were produced.

- The number of functioning fur farms in 2016 was 1144 (including 400 chinchilla farms) with annual income 400-600 million Euro and export value of over 1,3 billion zloty.

- The industry generates the income of public finances assessed on the level of over half million zloty, is a sponsor of local initiatives and enterprises, contributes to a technical industry in a borough, initiates and develops cooperation with a lot of cooperating industries.

- The owners and employees of the fur farms pay taxes to the state budget and the budgets of the local governments as well as insurance and pension contributions and due to functioning of fur farms in boroughs a lot of work places were established resulting in a low unemployment level.

\section{References}

1. Blomstedt, L.: Histological determination of different stages of pelage development, fur growth of mink. Acta Agriculturae Scandinavica 39(1), 91-99 (1989), DOI: 10.1080/00015128909438501.

2. Cholewa, R.: Cechy fizyko-mechaniczne włosów lisów polarnych. Roczniki Akademii Rolniczej w Poznaniu, 261(November 1994), 21-27 (1994).

3. Fur Industry by Country, http://www.fureurope.eu/fur-information-center/fur-industry-bycountry/, last accessed 2017/08/20.

4. Główny Urząd Statystyczny, http://stat.gov.pl/banki-i-bazy-danych/, last accessed 2017/10/26.

5. Kondo, K., Ninomiya, Y., Ichikawa, H., Kato, M., Fukunaga, S., Kondo, Hosaka, A.: Hair density and morphology of medulla in Mustelidae. SCIENTIFUR 28(3), 283-287 (2004).

6. Piórkowska, M.: Cechy funkcjonalne i wady okrywy włosowej u wybranych hodowlanych i dziko żyjących gatunków Canidae. Instytut Zootechniki PIB, Kraków (2015).

7. Price Waterhouse Coopers: Wpływ ekonomiczny branży hodowli zwierząt futerkowych na gospodarkę

Polski. https://www.pwc.pl/pl/publikacje/assets/wplyw_ekonomiczny_branzy_hodowcow_zwierz at_futerkowych_na_gospodarke_polski_2014.pdf, last accessed 2017/09/24.

8. Łapiński, S., Niedziółka, A. et al.: The impact of fur farming on the local economy in Poland. Agricultural University, Krakow 2017.

9. Vaněk, M., Hanzlová J.: Surface morphology and innervation of defective guard hairs of American mink - Lutreola vison (Schreber, 1774). Norwegian journal of agricultural sciences, 9(supplement), 629-636 (1992). 